\title{
舌切除後の機能
}

\section{一f-MRI を用いての検討一}

${ }^{1)}$ 山梨医科大学耳鼻咽喉科

2) 山梨医科大学脳神経外科

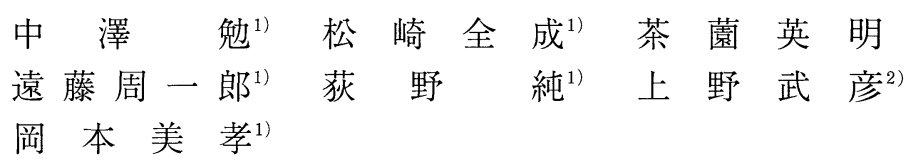

\section{論文要旨}

以前より舌切除後再建の機能については燕下機能や構音機能について多施設で検討されてきた。今回我々 は, 舌機能と共に非侵襲的な脳活動の画像化の新しい方法として数年前から始められた functional MRI （f-MRI）を用いて検討した。f-MRIは，脳賦活時に静脈のdeoxy-へモグロビンの絶対的・相対的含有量の 低下に伴い，賦活領域の MRIの信号強度が増すといった原理を応用したものである。與下機能は，T3・4 症 例では舌・喉頭運動が高度に障害されていた。構音機能は，症例により様々であった。f-MRI 検査では，舌 運動において, $\mathrm{T} 3 \cdot 4$ 症例では健側の運動野のみの描出が認められ, T2 症例では半切してあるにもかかわら ず，両側の描出が認められた。味覚についてはいずれの症例も健側のみの描出で，中咽頭の味覚を反映して いない結果であった。

Key words : 敌切除 (hemiglossectomy), f-MRI (functional magnetic resonance imaging), 舌運動 (tongue movement), 味覚 (gustation)

\section{はじめに}

以前より舌切除後再建の機能は, 特に嘆下や構音機能 について多施設で検討されてきた。今回我々は, 舌機能 と共に非侵襲的な脳活動の画像化の新しい方法として数 年前から Belliveau ${ }^{1)}$ や Ogawa ${ }^{2)}$ らよって始められた functional MRI（f-MRI）を用い検討した。

f-MRIの原理は, いわゆる BOLD（blood oxygenation dependency) 効果を応用したものである。 脳が局所的に活性化すると, 局所酸素消費量の増加を補 うためにその部位の血流量, 血液量が増加する。増加し た血液中には oxy-へモグロビンが多く含まれるため, 活性化部位では oxy-ヘモグロビンの割合が増し，この oxy-へモグロビンは反磁性であり磁気的には無視でき るが, 酸素を放出した deoxy-へモグロビンは常磁性で あり，磁場を乱す。MRIでは磁場が局所的に乱れると， その部位からの MRI 信号の位相が乱れ, 信号強度が減 少する。つまり活性化により血液量が増えることで, 相 対的にdeoxy-ヘモグロビンの割合が減り, 局所的に磁 場の乱れが減少し信号量が増加するといった原理である (図 1)。

下肢切断の場合には, f-MRI が幻肢の評価に有用で

別刷請求先: $\bar{\top} 409-3898$

山梨県中巨摩郡玉穂下河東 1110 山梨医科大学耳鼻咽喉科学教室 中澤 勉
はないかとされている。

\section{方 法・結 果}

対象は，舌部分切除以上を施行した患者で f-MRI 検 査の同意の得られた方を対象とした。 $\mathrm{T} 2$ 症例は，2 例 でいずれも患側の頸部郭清を行い, T3 以上の症例は, 3 例で両側頸部郭清後いずれの症例も pull throughにて en blockに腫瘍を摘出した。嚥下機能検査は, $5 \mathrm{cc} の$ バリウムを用い透視下ビデオ撮影を行い, 撮影後に嚥下 研究会のレジメに従い評価した。構音機能については構 音検査思案の「パンダ」で始まる 50 単語について評価 した。f-MRI 検査は, 舌の運動とチューブから食塩水 を遠隔注入し味覚刺激を行った。撮像装置は, GE 社の 1.5 テスラ臨床用 MR 装置を用い, スライス幅は $5 \mathrm{~mm}$, 軸位に 6 スライス撮影し，2秒ごとの信号取り込みを行っ た。BOLD 検出のための条件は, エコー時間 $60 \mathrm{~m}$ 秒, フリップ角 $90^{\circ}$ で行った。今回は術後の評価の及行った。

舌の運動は反対側の中心前回下部で行われるとされて いる。Wildgruber $ら^{33}$ は, 舌の垂直運動で両側の中心 前回下部の賦活をきたすと報告している。そこで我々は, 口を閉じた状態で舌の運動を行う課題を 20 秒間課して 3 回記録した。図 2-A は 20 秒間 10 イメージの ON/ OFF の信号強度を示し, 有意の信号上昇を認めた部分 を原画像に重㸚わせたのがこの図 2-B である。四の 如く両側中心溝上の静脈の信号の増強が認められ, 中心 前回の舌運動領域の賦活を反映するものと考えられた。 


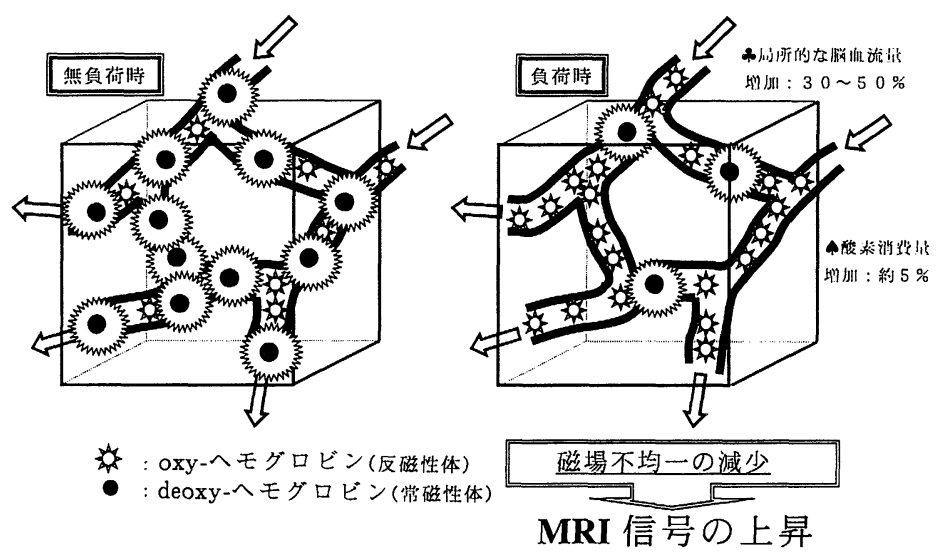

図 1 oxy-ヘモグロビンとdeoxy-ヘモグロビンの脳賦活時の変化と MRI信号変化。 deoxy-へモグロビンは常磁性体で, 周囲の磁場を大きく乱す。周囲の水分子はその磁場 の乱れの影響を受け，見かけのT2緩和時間が大幅に短くなる。oxy-ヘモグロビンは反磁 性体のため, 周囲の水分子に対する影響はない。従って, 血管内ではdeoxy-へモグロビ ンの存在分だけ信号強度が低下している。脳が活動すると, その対応する局所脳の脳血 流量 $(\mathrm{CBF})$ や脳血管床 ( CBV) は大きく増加する。しかし, 酸素消費量の増加はさほ ど大きくないためdeoxy-へモグロビンに比べて oxy-へモグロビンの量が多くなる。その 結果信号強度を弱めていた deoxy-ヘモグロビンの影響が弱くなり, MRIの信号強度が増 すことになる。

味覚路は，味覚信号が味蕾と自由神経終末より顔面神 経・舌咽神経及び迷走神経を経て, 延随孤束核へ伝わり, 同側の頭頂弁蓋と島皮質縁の皮質面へ達するとされてい る。村上ら ${ }^{4)}$ は，島及び弁蓋部以外にも特に前頭部にも 賦活領域が認められ, 記憶・感情等の反応とも関係があ るのではないかと報告している。頭をしっかり固定し， チューブを銜えてもらい 40 秒間水道水を嚥下しない程 度に遠隔注入し, 次の 40 秒間少量の食塩水刺激を行い 撮影した。両側島・弁蓋部の脳表に近い部分に信号強度 の上昇を認めた（図 2-C)。

\section{症例}

〔症例 1〕手術時 58 歳女性，3年前に舌左方を中心に 2/3 と左扁桃を切除し腹直筋で再建した T3 症例（図 3A)。いずれの症例も舌下神経は甲状舌骨筋枝分岐末梢 で切断した。日常生活に支障なく非常に活発な方で, 会 話も不自由ない方である。食事も普通食摂取が可能であ るが, 與下機能は, 舌運動に高度障害を示し, 口腔期 · 咽頭期の喉頭運動にまで障害が認められた。構音機能は, $\lceil ル 」($ 舌尖・歯茥),「チ・シ」(前舌面・硬口蓋) の構 音障害が認められた。f-MRI では, 舌運動で左の中心 前回下部のみの賦活が認められ (図 3-B), 味覚では右 の島皮質縁と脳表に賦活が認められた（図 3-C）。

〔症例 2〕手術時 54 歳男性, 6 年前に舌左方 $3 / 4$ と左 扁桃を切除し腹直筋皮弁で再建したT3 症例（図 4-A）。 舌根とわずかに右の舌が残り，日常生活に支障なく比較
的活発な方である。燕下機能は，舌運動に高度障害を示 し, 口腔期・咽頭期の喉頭運動にまで障害が認められた。 日常では普通食を捸取しているが, 検査中喉頭静止時に 誤嚥が少量認められた。構音機能は,「ス・ル・ゾ」（舌 尖)，「ヒ」(中舌面・硬口蓋）の構音障害が認められた。 f-MRIでは，舌運動で左の中心前回下部のみの賦活が 認められ (図 4-B)，味覚では右の島皮質縁に賦活が認 められた（図 4-C)。

〔症例 3〕 手術時 65 歳男性, 口腔底癌の症例で, 4 年 前に舌左方 $2 / 3$ と左扁桃と左下顎骨体部を区域切除し血 管柄付き腓骨と腹直筋皮弁で再建した T4 症例（図 5-A)。 日常生活では食事は時にむせる程度であるが, 会話は義 歯がうまく合わず，身内の方に限られている。嚥下機能 は, 口腔期・咽頭期の喉頭蓋運動に至るまでの障害があっ た。構音機能は,「ハ・ホ」(唇),「夕・サ・ツ」(舌尖・ 歯茎),「チ」(前舌面・硬口蓋),「カ・コ・ケ」(奥舌面・ 軟口蓋) の構音障害が認められた。f-MRIでは, 舌運 動で左の中心前回下部と右の舌下神経の補足運動野と思 われる部分の賦活が認められ (図 5-B), 味覚では右の 島皮質縁に賦活が認められた（図 5-C）。

〔症例 4〕手術時 65 歳男性, 1 年前に舌左側を半切し 前腕皮弁で再建した T2 症例（図 6-A）。日常生活に支 障なく生活されている方だが，一人暮らしであり会話は されない。嚥下機能は, 舌運動に中等度障害を示し, 口 腔期はバリウムの貯留がなく咽頭に流入するが, 咽頭期 に異常はなかった。構音機能は,「サ・ツ・リ」（舌尖・ 
(A)

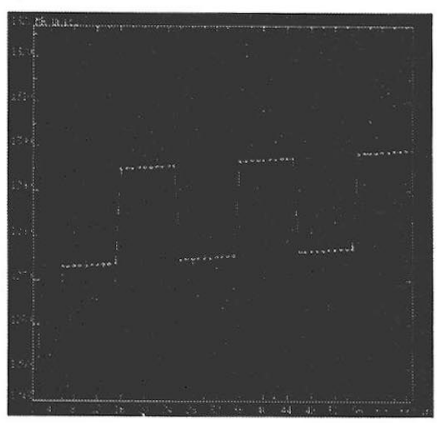

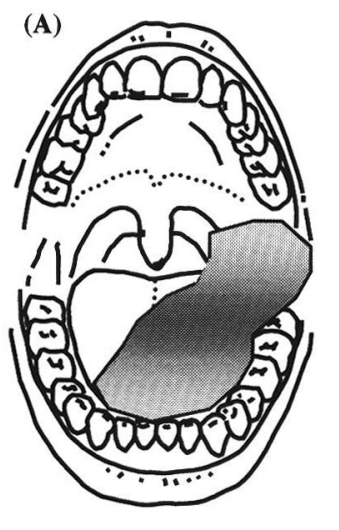

(B)

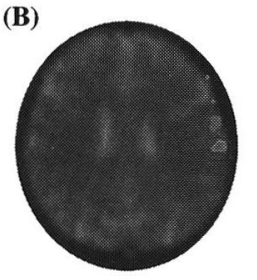

(C)

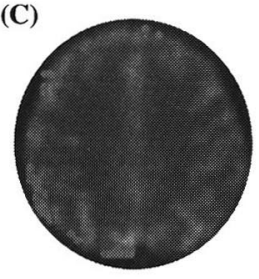

(B)

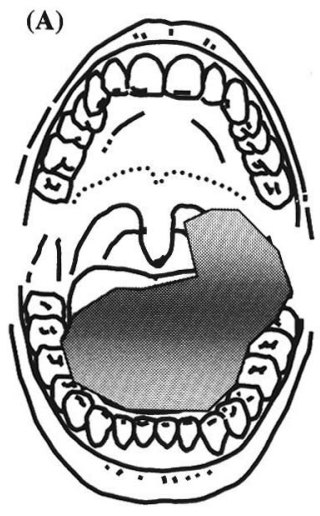

(B)

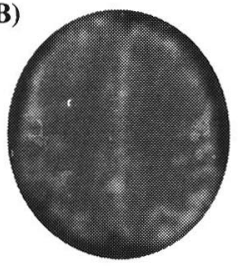

(C)

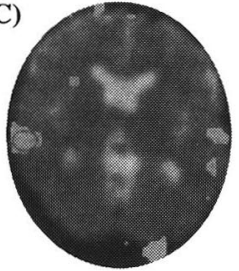

図 2 舌の運動・味覚にお忛るf-MRI像

舌垂直運動に㧍ける20秒間 10 イメージの ON/OFFの 信号強度 (A)。有意の信号上昇を認めた部分を原画像 に重㸚合わせたもの（B)。塩水刺激により両側島・弁蓋 部の脳表に近い部分に信号強度の上昇を認めた $(\mathrm{C})$ 。

図 3 〔症例 1〕手術時 58 歳女性。

3 年前に舌左方 $2 / 3$ と左扁桃を切除し腹直筋で再建した $\mathrm{T} 3$ 症例の切除範囲( A)。f-MRI; 舌運動で左の中心前 回下部のみの賦活が (B), 味覚では右の島皮質縁と脳表 に賦活が（C）認められた。
図 4 〔症例 2〕手術時 54 歳男性。

6 年前に舌左方 $3 / 4$ と左扁桃を切除し腹直筋皮弁で再建 したT3 症例の切除範囲 (A)。f-MRI; 舌運動で左の中 心前回下部のみの賦活が (B), 味覚では右の島皮質縁に 賦活が（C）認められた。 

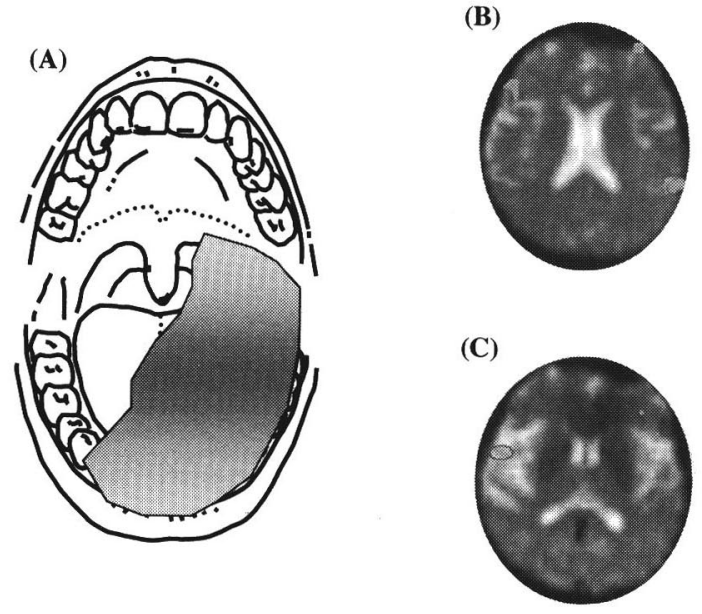

図 5 〔症例 3〕手術時 65 歳男性。

口腔底癌の症例で, 4 年前に舌左方 $2 / 3$ と左扁桃と左下 顎骨体部を区域切除し腓骨と腹直筋皮弁で再建した T4 症例の切除範囲 (A)。f-MRI; 舌運動で左の中心前回下 部と右の舌下神経の補足運動野と思われる部分の賦活が (B)，味覚では右の島皮質縁に賦活が（C）認められた。

(B)
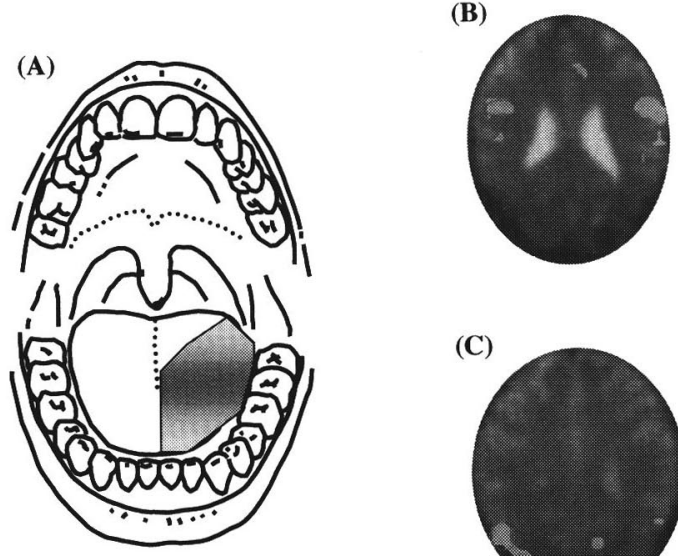

(C)

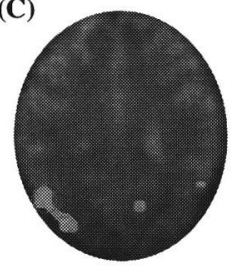

図 6 〔症例 4〕手術時 65 藏男性。

1 年前に左舌を半切し前腕皮弁で再建した $\mathrm{T} 2$ 症例の切 除範囲 (A)。f-MRI; 舌運動で左右の中心前回下部の賦 活が（B），味覚では右の島皮質縁と脳表に賦活が（C） 認められた。

(B)

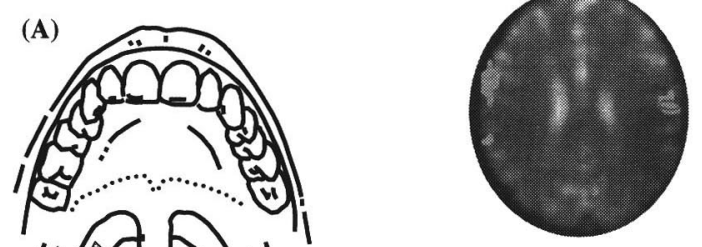

(C)

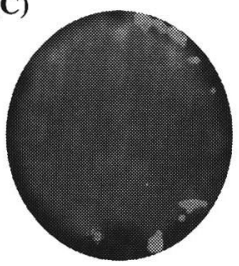

図 7 〔症例 5〕手術時 67 歳女性。

2 年前に右舌半切と右扁桃下極を切除し前腕皮弁で再建 した $\mathrm{T} 2$ 症例の切除範井 (A)。f-MRI; 舌運動で左右の 中心前回下部の賦活が (B), 味覚では左の島皮質縁と脳 表さらに左の前頭部にも賦活が（C）認められた。 
歯茎),「シ・チ」(前舌面・硬口蓋) の構音障害が認め られた。f-MRIでは, 舌運動で左右の中心前回下部の 賦活が認められ (図 6-B), 味覚では右の島皮質縁と脳 表に賦活が認められた（図6-C)。

〔症例 5〕手術時 67 歳女性, 2 年前に右舌半切と右扁 桃下極を切除し前腕皮弁で再建した T2 症例（図 7-A）。 日常生活に支障なく生活されている方である。燕下機能 は, 舌運動に左右非対称があるのみで, 構音機能も正常 である。f-MRI では, 舌運動で左右の中心前回下部の 賦活が認められ (図 7-B), 味覚では左の島皮質縁と脳 表さらに左の前頭部にも賦活が認められた（図 7-C）。

\section{考察}

口腔・舌癌切除後に遊離皮弁で再建することで, 舌の 機能は大いに向上している。今回, 舌切除後患者の機能 評価を嚥下・構音機能について行った。嚥下機能につい ては, 口腔期の障害は軟口蓋の切除範囲も大きく関与す ると考えられたが, 軟口蓋への切除を行った症例 5 では 口腔期に障害を認めなかった。 $\mathrm{T} 3 \cdot 4$ 症例で舌の切除が $2 / 3$ 以上になると舌・喉頭運動が高度に障害されていた。 症例 2 では少量ではあるが誤嚥も確認された。構音機能 については, 症例により様々で, 症例 5 を除いては, 舌 尖を使う構音に障害が認められた。また舌面を使った構 音は症例により異なっていた。このことは症例により切 除範囲は似ていても, 異なる生活環境及び術後の期間と さらに個々のリハビリにより代償的に構音可能になるの だと考えられた。我々の大学では構音についての訓練は 行っていないが, 今後舌尖や舌面を使った構音を可能と すべくリハビリの導入を考えるべきだと思われた。同時 に行った脳の機能を非侵襲的によく描出するf-MRI 検 查では, 舌運動において, 症例 $1 \cdot 2$ は健側の運動野のみ の描出が認められ, 症例 3 では患側の補足運動野の描出 が認められ, 症例 $4 \cdot 5$ では半切してあるにもかかわら ず, 両側の描出が認められた。これらの違いは, 代償過 程の個々のケースによる相違を示すもので, 切除範囲と 重ね合わせて検討を進めていく必要がある。味覚につい てはいずれの症例も健側のみの描出で, 症例 $1 \cdot 5$ では 何らかの感情の移入があったのか前頭葉の描出も認めら れた。味蕾は舌のみならず, 軟口蓋を含む中咽頭にも存
在しているが, 今回の f-MRI 検査では健側のみの描出 であった。脳神経の大半を扱う我々耳鼻科医にとっても, 脳機能評価にこの f-MRIが有用なものと考えられた。 特に, 代償過程を検討していくことは, 術後のリハビリ を考える上でも非常に意義が梁いと考えられる。今後, 更に症例数を増やし検討を重ねていくつもりである。

\section{結 語}

1. 舌切除後の嚥下. 構音機能に加え, 舌運動・味覚 についてf-MRIを用い検討した。

2. T2 症例においては, 術後ほとんど問題なく日常 生活を送っているが, 嚥下・構音機能には多少の障害が 認められた。

3. T3・4 症例においては, 経口摂取が可能でも嚥下 機能の障害は高度で, 構音機能の障害も舌尖 ·舌背・ 蓋の構音に障害が認められた。

4. 同時に行った f-MRI 検査では, 舌運動において, $\mathrm{T} 2$ 症例で両側の舌運動野が描出され, $\mathrm{T} 3 \cdot 4$ 症例で健側 のみの描出が認められた。味覚において, いずれの症例 も健側のみの描出が認められた。

5. 舌切除後の代償過程の検討に $\mathrm{f}-\mathrm{MRI}$ 検査の意義 は高いと考えられた。

尚, 本論文は, 平成 13 年 6 月 21,22 日, 第 25 回日本 頭頸部腫瘍学会 (札幌)において発表した。

\section{文献}

1) Belliveau JW. et al: Functional mapping of the human visual cortex by magnetic resonance imaging. Science 254: 716-19, 1991.

2) Ogawa S. et al: Oxygen sensitive contrast in MRI in rodent brain at high magnetic fields. Magn Reson Med 14:68-78, 1990.

3) Wildgruber D. et al: Functional lateralization of speech production at primary motor cortex. Neuroreport $7: 2791-5,1996$.

4）村上秀明 他：Functional MRIを用いた味覚刺激に よる脳賦活領域の同定の可能性. 日本口腔外科学会 雑誌 48(5)：391-4, 1999. 


\title{
THE EVALUATION OF SPEECH AND OF SWALLOWING IN PATIENTS WITH TONGUE CANCER WHO UNDERWENT RESECTION FOLLOWED BY RECONSTRUCTION, USING FUNCTIONAL MAGNETIC RESONANCE IMAGING (f-MRI)
}

\author{
Tsutomu NAKAZAWA ${ }^{1)}$, Zensei MATSUZAKI ${ }^{11}$, Hideaki $\mathrm{CHAZONO}^{12}$, \\ Shyuuichiro ENDO ${ }^{1)}$, Jun OGINO ${ }^{1)}$, Takehiko $\mathrm{UENO}^{2)}$, \\ and Yoshitaka OKAMOTO ${ }^{11}$ \\ Dept. of Otolaryngology ${ }^{1)}$ \& Neurosurgery ${ }^{2)}$, \\ Yamanashi Medical University
}

The swallowing and speech functions in patients with tongue cancer who underwent resection followed by primary reconstruction with free flaps, were examined at many hospitals. The brain activities induced by tongue movement or with taste were also examined by using functional magnetic resonance imaging (f-MRI) which has been developed recently for new imaging. The principle of $\mathrm{f}-\mathrm{MRI}$ is that the brain activities induce the reduction of the brain venous deoxyhemoglobin and eventually enhance the potentials of MRI. The tongue and laryngeal movement were severely disturbed in the extensively tongue resected patients during swallowing, however, the speech production was not always even in these patients. By f-MRI examination, the tongue movement led to the potential of the healthy motor cortex side in the extensively resected patients, and of both symmetrical activation of motor cortices in hemiglossected patients. As for the gustation, even the oropharyngeal gustatory field was resected, f-MRI examination revealed the activation of the healthy gustatory cortex in all patients. 